\title{
Starość z perspektywy seniorów jako ważny głos we współczesnej refleksji geragogicznej Recenzja monografii Artura Fabisia pt.: Troski egzystencjalne w starości. Ujęcie geragogiczne, Kraków 2018, Wydawnictwo Naukowe Uniwersytetu Pedagogicznego
}

\begin{abstract}
Abstrakt
Tekst jest recenzją monografii habilitacyjnej Artura Fabisia opublikowanej w $2018 \mathrm{r}$. przez Wydawnictwo Naukowe Uniwersytetu Pedagogicznego w Krakowie. W zwięzłej, syntetycznej formie podjęto dyskusję wokół przyjętych w pracy głównych kategorii pojęciowych, teoretycznych i metodologicznych przesłanek koncepcji badań, a także wartości poznawczej analiz i interpretacji wywiedzionych ze zgromadzonego materiału badawczego. Zwrócono również uwagę na oryginalny charakter i walory niniejszej publikacji.
\end{abstract}

Słowa kluczowe: starość, starzenie się, troski egzystencjalne, wartość życia, nieuchronność śmierci, radzenie sobie z problemami egzystencjalnymi.

Old Age from the Viewpoint of Seniors as an Important Comment in Modern Geragogic Reflection: Review of the Monograph by Artur Fabiś Entitled Troski egzystencjalne w starości. Ujęcie geragogiczne, Kraków 2018, Wydawnictwo Naukowe Uniwersytetu Pedagogicznego

\begin{abstract}
The paper is a review of the habilitation monograph by Artur Fabiś published in 2018 by Wydawnictwo Naukowe Uniwersytetu Pedagogicznego in Krakow. In a concise, synthetic form, a discussion is undertaken around the main conceptual, theoretical
\end{abstract}

* Uniwersytet Łódzki, Wydział Nauk o Wychowaniu, Katedra Andragogiki i Gerontologii Społecznej. 
and methodological premises of the research concept adopted in the paper as well as the cognitive value of analyses and interpretations derived from the collected research material. The paper also draws the attention of the readers to the original character and advantages of that publication.

Keywords: old age, ageing, existential concerns, value of life, inevitability of death, coping with existential problems.

Tajemnica ludzkiego istnienia bodaj najpełniej wybrzmiewa w perspektywie starości odczytywanej jako zapowiedź kresu życia i symbol pogrążenia się w nicości lub przejścia do wieczności. Bezradność człowieka w zrozumieniu życia poza jego granicami czyni ze starości szczególny etap otwierający przed nim różne pola rozwoju, ale i ryzyko osobowej degradacji.

Integralnym komponentem starości jest wewnętrzne napięcie wywołane tym, co nieuniknione i niezmienne, czemu nie można zapobiec i przed czym nie można się uchronić, co niesie definitywny kres - świadomością nieuchronności własnej śmierci. Nieprzeniknioność tej tajemnicy obejmuje każdy wymiar ludzkiego istnienia, wywołuje niepokój egzystencjalny, a często paraliżującą trwogę przed tym, co czeka człowieka poza granicą śmierci. Tajemnica życia rozpoznawana z perspektywy nieuchronności śmierci zajmuje ludzkie umysły i serca, jest immanentnym komponentem tekstów kulturowych, debat społecznych i dyskursów naukowych. Odciska swoje piętno również na stosunku do świata i życia współczesnego człowieka. Towarzyszące mu odwieczne pragnienie wyzwolenia się spod jarzma śmierci nieustannie podsyca jego dążenie do zrozumienia natury świata, które rozwija się w dwóch przeciwstawnych kierunkach: uchwycenia sensu ludzkiego życia i śmierci, harmonizującego wolę życia ze świadomością przygodności własnego bytu oraz przejęcia kontroli nad procesami starzenia się i ostatecznie przezwyciężenia śmierci, zmieniającego naturę ludzkiego istnienia.

Pierwszy z wymienionych kierunków odniesienia się do życia i śmierci jest bliski dr. hab. Arturowi Fabisiowi, autorowi monografii Troski egzystencjalne w starości. Podejmuje w niej wciąż aktualną i ważną problematykę konfrontowania się ludzi starych z egzystencjalnymi aspektami życia. Usytuowanie tej problematyki w przestrzeni życiowej ludzi starych nie jest przypadkowe. W starości bowiem wspomniany Autor dostrzega szczególny potencjał autorefleksyjnego odniesienia się do istoty życia rozpatrywanego w perspektywie jego kruchości i skończoności. Konstytutywnymi składnikami tego potencjału jest doświadczenie życiowe i dojrzałość osobowa, których emanacją jest mądrość życiowa seniorów, a także ich dystans do tego, co nieuniknione w ludzkim życiu. Ów dystans kształtuje się na podłożu świadomości upływającego czasu i bezsilności wobec zbliżającego się kresu własnego życia. Starość jest w tym kontekście szczególnym „okresem życia najbardziej wrażliwym na troski egzystencjalne”, który wspomniany Autor zdaje się odczytywać jako wartość autoteliczną wyznaczającą horyzont zainteresowań badawczych. 
Wartość i oryginalność tej pracy dostrzegam w kilku aspektach, które konstytuują oś konstruktu myślowego mającego bezpośrednie przełożenie na konceptualną i konkluzywną warstwę niniejszej monografii. Mam na myśli: a) afirmatywny stosunek do starości jako równowartościowego etapu dorosłości człowieka, b) usytuowanie w centrum dyskursu doświadczeń biograficznych seniorów jako podmiotów faktycznie doświadczających starości i ją autorefleksyjnie przeżywających, c) twórczy charakter analiz zgromadzonego materiału badawczego, czego wyrazem jest autorska propozycja typologii starzenia się i radzenia sobie z problemami egzystencjalnymi, a także d) osadzenie problematyki badawczej w perspektywie geragogicznej, co z punktu widzenia jej rozwoju ma niewątpliwie istotne znaczenie.

Afirmatywny stosunek Autora do starości wyraża się w swoistym dowartościowaniu tego etapu życia ze względu na wyeksponowaną w nim konieczność odniesienia się do istoty życia w obliczu nieuchronności śmierci. W starość rozpatrywaną z tej perspektywy wpisany jest swoisty „przymus” egzystencjalny, który na tym etapie życia staje się szczególnie doniosły. Wówczas symbolizuje ona czas intensywnej pracy człowieka starego nad sobą, polegającej na konfrontowaniu się z podstawowymi kwestiami egzystencjalnymi; szczególne wyzwanie, które nie jest obojętne dla osiągania dojrzałości osobowej. Z jednej strony jest szansą daną człowiekowi na uchwycenie wartości własnego życia rozpoznawanego w świetle nieuchronności śmierci, z drugiej zaś strony niesie ryzyko rozpaczy utożsamianej z przeświadczeniem o bezsensowności życia, którego kres przekreśla wszelką jego celowość i sensowność.

Przyjęta w pracy perspektywa rozumienia starości i trosk egzystencjalnych sprzyja dostrzeżeniu wartości poznawczej osobistych doświadczeń biograficznych seniorów. Ich autentyczność uzasadnia uznanie faktu, iż nikt lepiej od seniorów nie jest w stanie odsłonić specyfiki starości. A tym samym związanych z nią: trudności, ograniczeń, deficytów i upośledzeń; cierpienia wywoływanego utratą zdrowia i sił witalnych, zależnością od innych, samotnością, realnością śmierci; zarazem też afirmacją życia, radością realizowania się w różnych obszarach aktywności, satysfakcją z pozytywnego bilansu życia; nadzieją na to, że śmierć nie jest definitywnym kresem życia.

Osobiste doświadczenia biograficzne stanowią punkt wyjścia do analiz, interpretacji i konceptualizacji autorskich typologii będących udaną - w moim przeświadczeniu - próbą rozumiejącego wglądu Autora w badane zjawisko. Znajduje to wyraz w strukturze książki, której konstrukcja - poza pierwszym rozdziałem będącym wprowadzeniem do teoretyczno-metodologicznych ram przedmiotu badań - jest sekwencją rozdziałów: Osiemnaście historii życia, Starość osób aktywnych edukacyjnie i Skończoność jako źródło trosk i wyzwań w starości. Walorem pracy jest w tym kontekście wnikliwe wydobywanie i wyjaśnianie subtelności znaczeń ukrytych w historiach życia seniorów. Wytyczają one sposoby zróżnicowanego odniesienia się seniorów do własnego życia, w którym przeplątają się per- 
spektywa retrospektywna z prospektywną; to, co minione, z tym, co antycypowane. W umiejętnie prowadzonym dyskursie naukowym Autor odsłania niejednorodny, wielobarwny i niekoherentny obraz, a raczej swoisty kolaż nieoczywistych sposobów rozumienia przez seniorów wartości, celów i sensów ich własnego życia w świetle doświadczanych przez nich trosk egzystencjalnych.

W kategoriach istotnego dokonania naukowego Artura Fabisia traktuję jego autorskie propozycje dwóch typologii wnoszących ważny wkład do rozumienia wielowymiarowej struktury badanego zjawiska. Do ich opracowania Autor wziął pod uwagę cechy starzenia się seniorów, tj.: akceptację własnej starości, aktywność edukacyjną, zaradność życiową, religijność i życie duchowe, a także postawy seniorów wobec kluczowych kwestii egzystencjalnych, w których wyrażają oni stosunek do własnej śmierci, samotności, bilansu życiowego i cierpienia. Pierwszą z nich jest typologia starości rozpoznawanej jako dynamicznie zachodzący proces starzenia się seniorów, który - jak wskazuje A. Fabiś - może przebiegać w czterech odrębnych przestrzeniach doświadczania starości: konfrontacyjnej, kontynuacyjnej, konsumpcyjnej i konstruktywnej. Natomiast druga typologia uwzględnia strategie radzenia sobie seniorów z problemami egzystencjalnymi. W zależności od indywidualnych postaw seniorów przejawianych w ich codziennym życiu wspomniane strategie rozkładają się na kontinuum od wypierającej, przez ucieczkową, po zaangażowaną.

Publikacja Artura Fabisia jest więc wartościową poznawczo pracą naukową. Prócz poszerzania wiedzy w przedmiotowym zakresie jest ona z punktu widzenia czytelnika interesująca i inspirująca. Autor merytorycznie i zarazem ze swadą prowadzi dyskurs naukowy w płaszczyźnie dyskusji koncepcji teoretycznych, założeń metodologicznych koncepcji badań własnych, a także analiz treści i konkluzji wywiedzionych ze zgromadzonego materiału badawczego. Należy w tym kontekście docenić również wartość materiału źródłowego. Daje on bowiem rzadką możliwość zapoznania się z wypowiedziami seniorów osadzonymi w sferze ich osobistych, autorefleksyjnych rozważań i przekonań dotyczących różnych aspektów egzystencji w praktyce życia codziennego. Co więcej, skłania do refleksji nad treścią ich namysłu nad naturą świata i zanurzonego w nim ludzkiego istnienia, którego konstytutywnymi cechami są przygodność, kruchość i skończoność.

Walorem tej publikacji jest również szerokie spektrum potencjalnych odbiorców. Sposób ujęcia problematyki badawczej i styl pisarski Autora czynią ją atrakcyjną zarówno dla nauczycieli akademickich, specjalistów praktyków, jak i dla niezwiązanych z tymi środowiskami czytelników-amatorów, kierujących się ciekawością fenomenu trosk egzystencjalnych w starości. Niewątpliwie książka Artura Fabisia zasługuje na to, by ją rekomendować szerokiemu gronu czytelników, co czynię z pełnym przekonaniem i radością. 